\title{
Magnetic polarity stratigraphy of the Siwalik sequence in Nurpur area, NW Himalaya, India
}

\author{
M VENKATESHWARLU* \\ Geochronology (TIMS) and Palaeomagnetism Studies, CSIR-National Geophysical Research Institute, \\ Uppal Road, Hyderabad 500 007, India. \\ *Corresponding author.e-mail: mamila_v@rediffmail.com
}

Magnetic polarity stratigraphy studies were carried out on Jabbar Khad section of Nurpur area, Kangra District, Himachal Pradesh, India. Oriented block samples were collected at 202 sites with 3-5 samples per site from a $2350-\mathrm{m}$ thick continuous sedimentary sequence consisting of sandstone-mudstone alternating beds. Specimens were subjected to thermal demagnetization $\left(100-700^{\circ} \mathrm{C}\right)$ after measuring their natural remanent magnetization (NRM). Palaeolatitudes of virtual geomagnetic pole (VGP) from each site were calculated from the acquired characteristic remanent magnetization (ChRM) directions. The observed remanence carrier could be haematite. Magnetic polarity scale (MPS) was erected. This MPS is correlated with the standard geomagnetic polarity time scale (GPTS) of Lourens et al. (2004). The MPS readily matched from chron C2An.1n to chron C4n.2n, therefore assigning an age 8.20-2.60 Ma to the middle and upper Siwalik sections at Nurpur. The rate of sedimentation in middle Siwalik is $29 \mathrm{~mm} / \mathrm{yr}$ and upper Siwalik is $59 \mathrm{~mm} / \mathrm{yr}$.

\section{Introduction}

Siwalik Group, exposed at the southern foothills of Himalaya, is well known for its mammalian faunas. Pilgrim (1913) proposed the faunal zonation for the Siwalik, but while recognizing the various faunal zones, lithology is used to distinguish various designated faunal zones. This has created lot of confusion, and the researchers found that lithology used to recognize the various zones is time transgressive. To overcome this confusion, American workers replaced lithology with magnetostratigraphy and sometimes clubbed vertebrate palaeontological studies (Opdyke et al. 1979; Barry et al. 1982; Johnson et al. 1982a, b; 1985). These researchers dated various stratigraphic and faunal events. Barry et al. (1982) even proposed four biostratigraphic interval zones pertaining to the middle Siwalik and to the lower part of the upper Siwalik.
Magnetostratigraphy plays a vital role in the correlation of regional strata (Tandon et al. 1984; Ranga Rao et al. 1988, 1995; Ranga Rao 1993; Sangode et al. 1996, 1999; Sangode and Kumar 2003). However, work on few sections in middle and upper Siwaliks was carried out by several researchers (Azzaroli and Nappoleone 1982; Johnson et al. 1983; Venkateshwarlu 1996, 2008, 2011; Kotlia et al. 1998, 1999, 2001, 2008; Brozovik and Burbank 2000; Nanda 2000; Sanyal et al. 2004, 2005; Sudheer Kumar 2004; Kumaraval et al. 2005; Sinha et al. 2005; Venkateshwarlu et al. 2005; François Chirouze et al. 2012); whereas paleontology studies in Nurpur area have been carried out by Nanda and Sehgal (1993) and Sehgal and Nanda (2002).

Continuous outcrop of middle and upper Siwalik sediments are exposed in Nurpur and this study has been taken up to fill the gap in the

Keywords. Magnetic polarity stratigraphy; GPTS; Siwaliks; Nurpur; Himachal Pradesh. 
database of magnetostratigraphy in the Neogene period, particularly the upper Siwalik and also to understand the dynamics of the molasse accumulation in Siwalik Basin.

\section{Geology}

The anticline structure in Nurpur is the southeasterly continuation of the Surin-Mastgarh anticline of the Jammu Hills where magnetic analysis of four sections: Balli, Jammu-Nagrota, ParmandalUtterbeni and Samba-Mansar, all falling on the southwestern flank of the anticline, were carried out by Ranga Rao (1986) and Ranga Rao et al. (1988). The present studied section of Jabbar Khad near Nurpur falls on the northeastern flank of the anticline.

Figure 1 is the geological map of the Himalayan foothills showing Nurpur section, Kangra district, Himachal Pradesh. The Nurpur sequence is inclined to northeast to east-northeast with dip amounts of $4-5^{\circ}$ near the axial region of the anticline increasing to $65^{\circ}$ upwards in the sequence. The Lower Siwaliks (Karunakaran and Ranga Rao 1976) consist of thick pile of sediments exposed near the core of the anticline, comprises of thick bright red coloured mudstones which alternate with thin sandstone beds. The claystones constitute about $65 \%$ of the total thickness. The sandstones are light grey in colour, fine grained and compact, often lenticular in nature, laterally changing to siltstone and mudstone. Above this sandstone, massive, soft, medium-grained sandstones appear with interbedded mudstones which are dull red or brown with grey-green marls.

Towards the top, thicker conglomerate bands appear along the Jabbar Khad and their total thickness is rather small. Pink and grey limestone pebbles are present in the conglomerates. These bear lithological resemblance to the Shali Limestone outcropping to the north of the Main Boundary Fault. The basal part of the topmost unit of the upper Siwalik sequence in this section was examined during the present work. It is constituted of thick cobble/boulder beds with very few mudstone bands. Therefore this sequence was not sampled.

\section{Sampling and palaeomagnetic analysis}

The Nurpur stream section was surveyed with prismatic compass and the geology is plotted on traverse sheets in order to construct lithostratigraphic column. Gautam and Rosler (1999) stated that given the frequency of magnetic reversals during

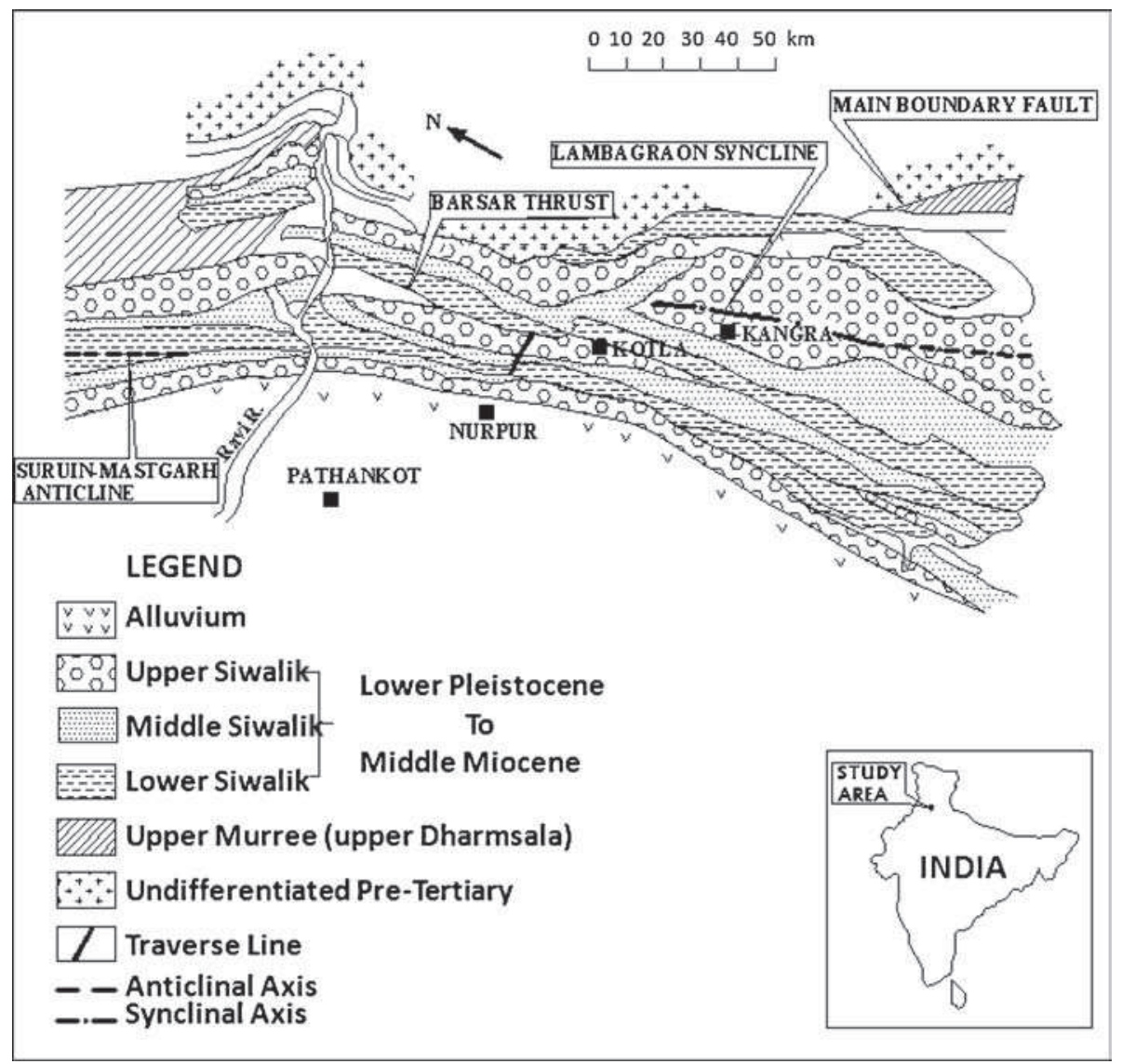

Figure 1. Geological map of the Himalayan foothills showing the study area at Nurpur, Kangra district, Himachal Pradesh, India. 
the Neogene and the average long-term rate of sediment accumulation in the Siwalik Group, an average spacing of $30 \mathrm{~m}$ should be sufficient to record most of the major polarity zones. The present section satisfies this criterion. The measured section from the anticline axis to the Massive Boulder Beds along Jabbar Khad is 2350-m thick. Three to five oriented samples were collected from each sedimentary horizon. Approximately 1000 oriented block samples were collected from 202 sites, mostly from claystones, siltstones and at few places from fine-grained sandstones where major gap appeared. Natural remanent magnetization (NRM) was measured using Schonstedt Spinner Magnetometer (Model DSM-2). Initial NRM intensities ranged from 0.30 to 3.93


Figure 2. Representative vector end-point diagram of thermal demagnetization behaviour for samples from middle-upper Siwalik sediments at Nurpur. Solid circle projections onto horizontal plane and open circle projections onto vertical plane. Numbers adjacent to data points indicate temperature in ${ }^{\circ} \mathrm{C}$.

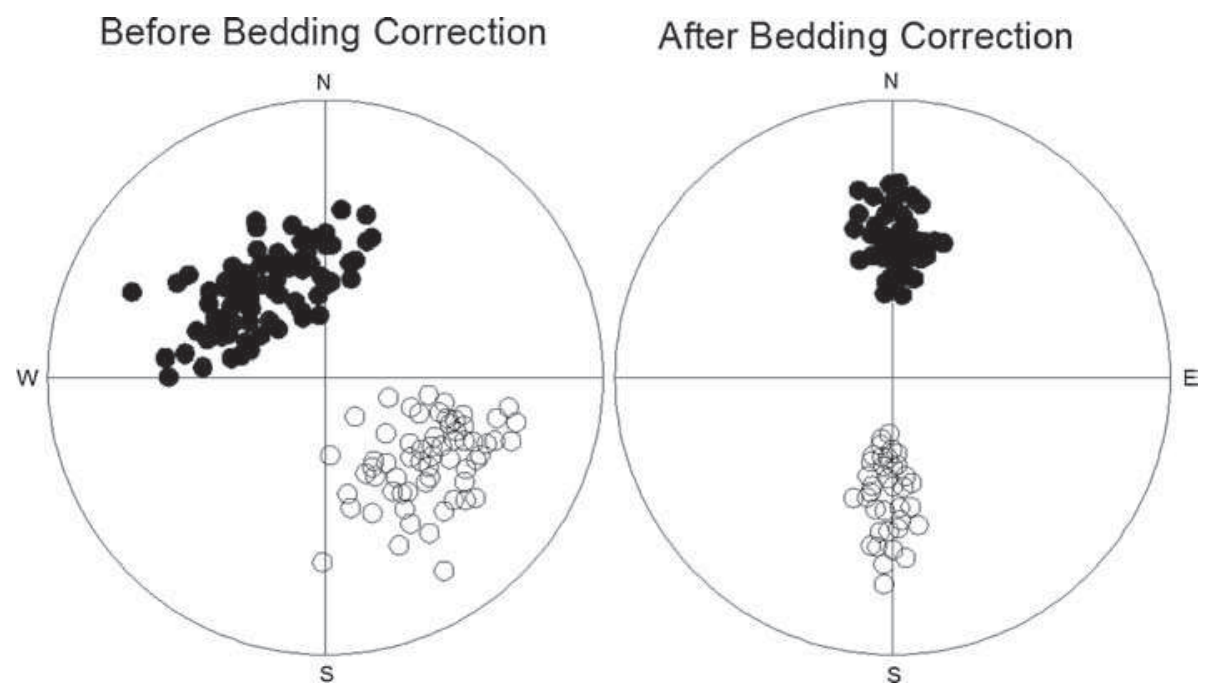

Figure 3. Equal area projections of site-mean ChRM directions (before and after bedding-correction) from Nurpur Siwaliks.

Table 1. Paleomagnetic results of Nurpur area - after bedding correction.

\begin{tabular}{|c|c|c|c|c|c|c|}
\hline Subgroup & No. of sites & $\mathrm{D}^{\circ}$ & $\mathrm{I}^{\circ}$ & $\mathrm{K}$ & $\alpha_{95}^{\circ}$ & Polarity \\
\hline \multirow{2}{*}{ Upper Siwaliks } & $\int 32$ & 9 & 25 & 11.01 & 8.02 & Normal \\
\hline & 39 & 182 & -41 & 19.35 & 5.35 & Reversed \\
\hline \multirow{2}{*}{ Middle Siwaliks } & $\int 61$ & 359 & 34 & 15.84 & 4.84 & Normal \\
\hline & 49 & 178 & -40 & 12.19 & 6.02 & Reversed \\
\hline
\end{tabular}


$\mathrm{mA} / \mathrm{m}$ with an average intensity of $1.05 \mathrm{~mA} / \mathrm{m}$. Samples were subjected to alternating field demagnetization (AFD) initially and found that this technique is not suitable for the Siwalik sedimentary rocks. Then progressive thermal
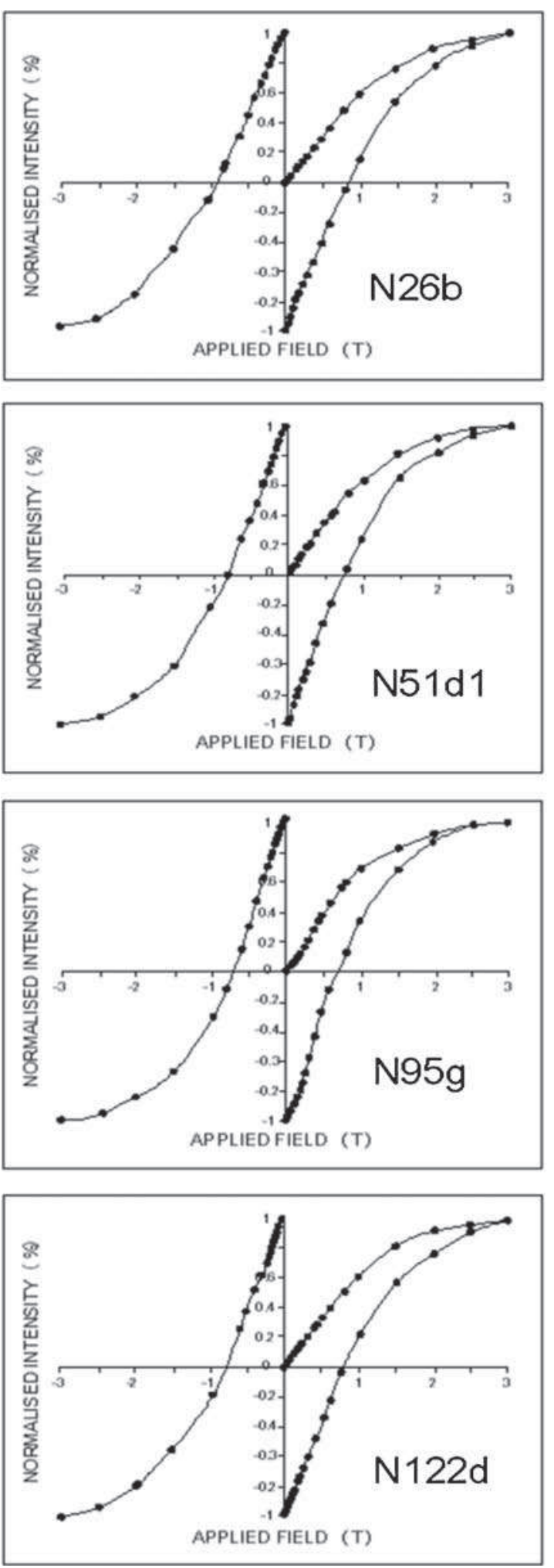

(a) demagnetization technique was adopted based on prior research on palaeomagnetism of Siwalik Group sedimentary rocks in India to isolate the characteristic remanent magnetization (ChRM) components.
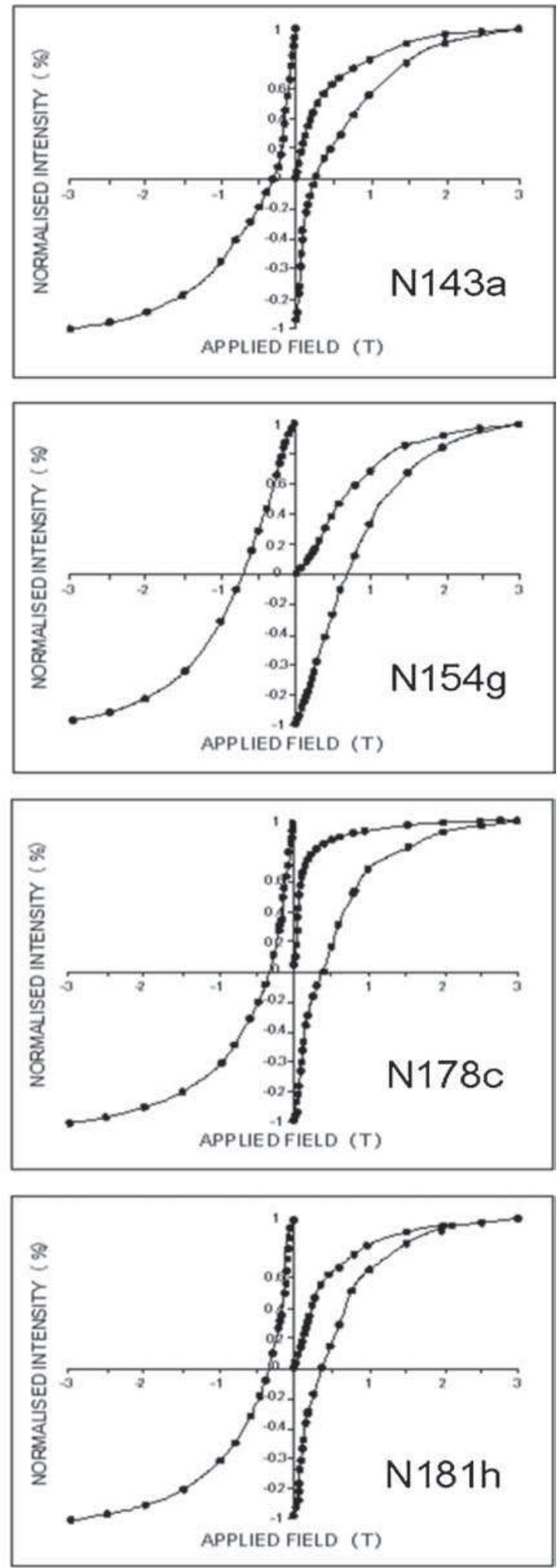

(b)

Figure 4. Isothermal remanent magnetisation (IRM) curves. (a) Middle Siwalik and (b) upper Siwalik. 


\subsection{Thermal demagnetization}

Progressive thermal demagnetization method was applied on specimens from 64 sites. The specimens were demagnetized using Schonstedt Thermal Demagnetizer (TSD-1) at 12-13 temperature steps from $100^{\circ}$ to $700^{\circ} \mathrm{C}$. Figure 2 shows the typical thermal demagnetization behaviours for middle and upper Siwalik samples. The high unblocking temperature components are carried by specular haematite that acquired a magnetization either as detrital remanent magnetization or chemical

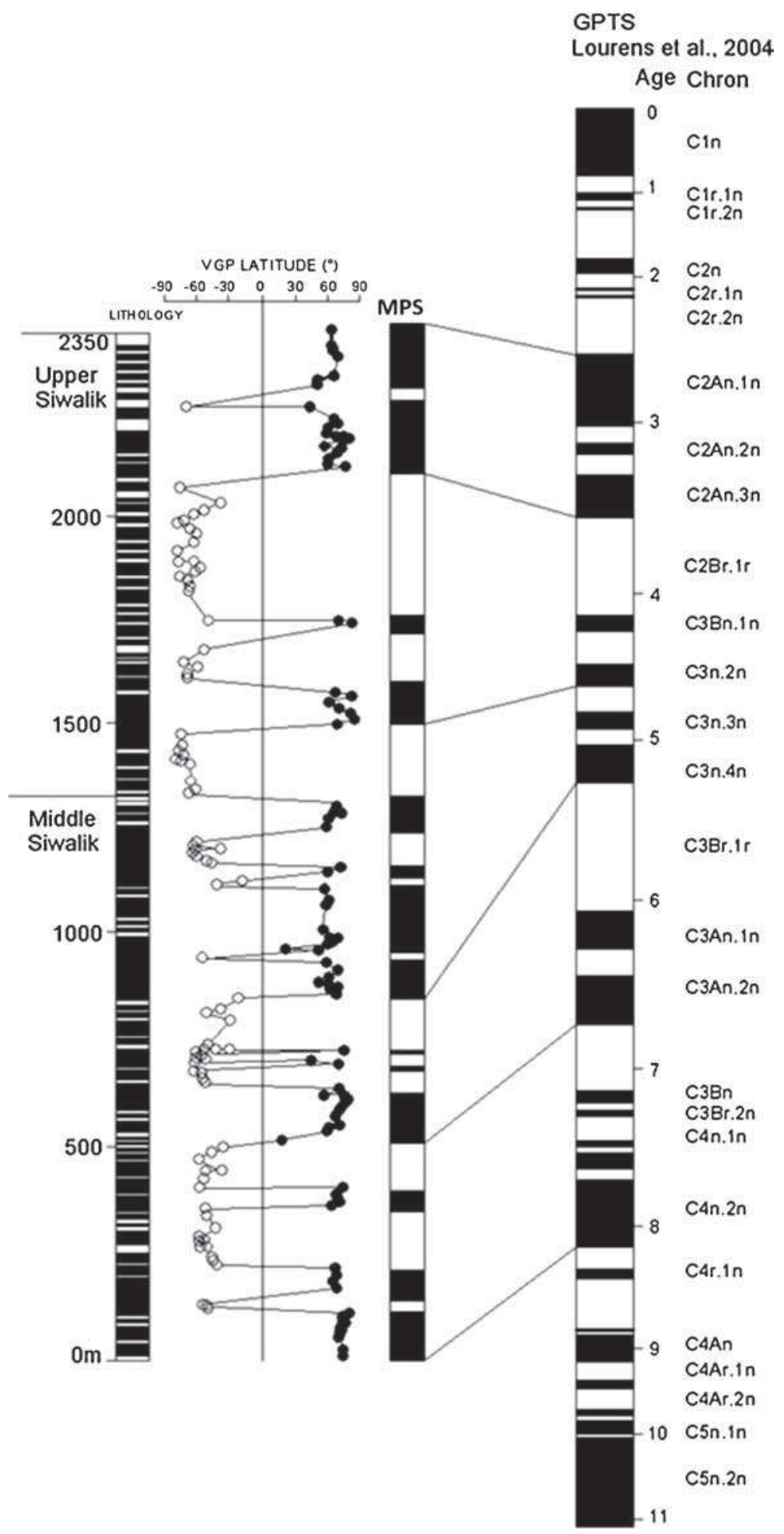

Figure 5. Plot of lithostratigraphy and magnetostratigraphy. Correlation of Nurpur MPS to the GPTS of Lourens et al. (2004). MPS: Magnetic polarity scale; GPTS: geomagnetic polarity time scale; m: meters. Alternate black and white shaded region represents normal and reverse polarities, respectively. 
remanent magnetization soon after deposition (Tauxe and Badgely 1988; Tauxe et al. 1990; Ojha et al. 2000).

Principal component analysis of NRM remaining at two to three successive temperature steps from $575-625^{\circ} \mathrm{C}$ was used to determine the ChRM (Kirschvink 1980). Site mean ChRM directions were calculated using Fisher (1953) statistics. Figure 3 shows the stereographic projection of ChRM directions before bedding and after bedding correction. It is observed that there is an improvement in the grouping of the site means' direction after bedding correction. The mean of normal polarity sites of middle Siwaliks is $359^{\circ}$ and $34^{\circ}\left(\alpha_{95}=4.84^{\circ}, \mathrm{k}=15.8\right)$, whereas mean of reverse polarity sites is $178^{\circ}$ and $-40^{\circ}\left(\alpha_{95}=6.02, \mathrm{k}=\right.$ 12.2). Similarly, mean of normal polarity sites of upper Siwaliks is $9^{\circ}$ and $25^{\circ}\left(\alpha_{95}=8.02^{\circ}, \mathrm{k}=11.0\right)$, whereas mean of reverse polarity sites is $182^{\circ}$ and $-41^{\circ}\left(\alpha_{95}=5.35, \mathrm{k}=19.4\right)$. Since, the $\mathrm{k}$-values for both polarity groups are low and the reversal test is indeterminate. Given the limited variation in bedding attitudes and low k-values (large dispersion), the implications of the fold test are uncertain. The shallowing of palaeomagnetic directions is likely the result of plate-like detrital haematite particles settling with long-axes subparallel to bedding (Tauxe and Kent 1984; Rosler and Appel 1998; Ojha et al. 2000) or post-depositional sediment compaction (Kodama 1997). Table 1 gives the details of paleomagnetic results of Nurpur section.

Rock magnetic experiments were performed to assess the magnetic mineralogy and to know the magnetic remanence carrier mineral. The blocking temperatures and coercivity of different components of magnetization have been determined using isothermal remanent magnetization (IRM) acquisition characteristics. Figure 4 shows the IRM curves for middle and upper Siwalik, indicating that the remanence in the red coloured rocks is probably carried by specular hematite. Susceptibility vs. temperature $(\mathrm{k}-\mathrm{T})$ studies were performed but the curves are not prominent enough to discriminate the remanent carrier mineral.

Virtual geomagnetic pole (VGP) latitudes were calculated for each site. Figure 5 shows the magnetic polarity stratigraphy (MPS). Although there is some uncertainty in correlating the base of the section to the GPTS, magnetic polarity zones show very good correlation to chrons $\mathrm{C} 4 \mathrm{n} .2 \mathrm{n}$ through

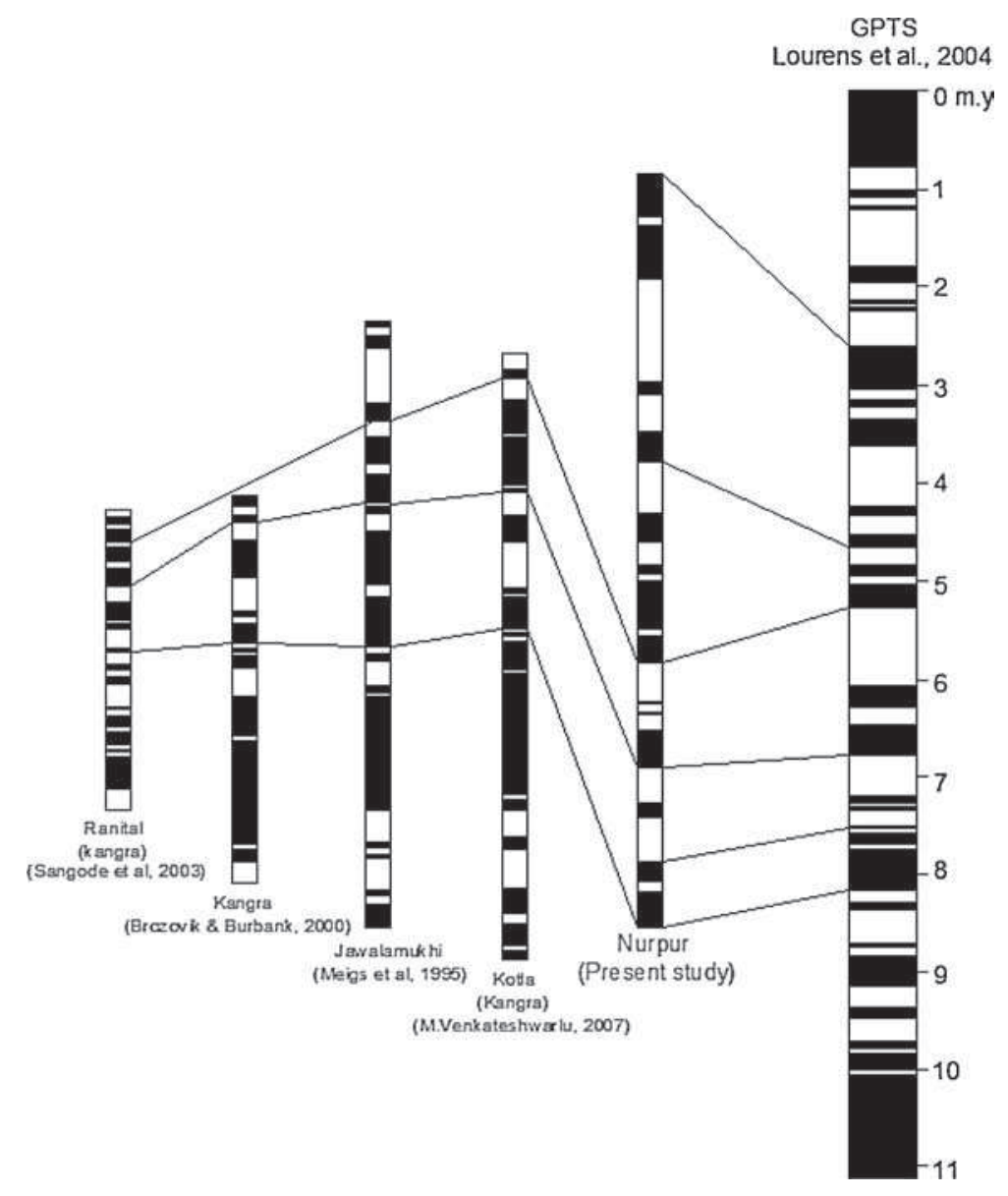

Figure 6. Regional correlation of Kangra sections with Nurpur section (present study). Alternate black and white shaded region represents normal and reverse polarities, respectively. 
C2An.1n of the GPTS (Lourens et al. 2004). The age range of the Siwalik Group at Nurpur is therefore indicated in the interval $\sim 8.2$ to $\sim 2.6 \mathrm{Ma}$ (figure 5).

The vertebrate fossils are known from Nurpur since 1913, when Hipparion and Amphicyon were reported from the red bed succession. The most common vertebrate fossil among the vertebrate fauna is the three-toed horse, Hipparion, which is restricted to the middle Siwalik (Nagri and Dhok Pathan) faunal zones of Pilgrim (1913). Its first occurrence in the Nurpur section is at $270 \mathrm{~m}$. No mammalian taxa having affinity with the lower Siwalik Subgroup is present in Nurpur (Sehgal and Nanda 2002). The above-mentioned data help in correlation of the Nurpur MPS to the GPTS.

\section{Discussion}

\subsection{Regional correlations}

Combined with previous work on magnetic polarity stratigraphy in Kangra, the new data allow for a regional correlation in the Siwalik Group (figure 6). The Siwalik Group correlations are based on the presence of long normal polarity zone that correlates with chron C5n.2n at 10-11.1 Ma, which is present in all the sections except in Nurpur. Above this, on reverse polarity interval C2Br.1r at $\sim 3.5-4.2 \mathrm{Ma}$ (Lourens et al. 2004) is recorded in all the sections including the present study section except in Kangra section. Ranital, Kangra, Jawalamukhi, Kotla and Nurpur are correlated with C4n.2n. The upper part of the Nurpur is correlated at $\mathrm{C} 2 \mathrm{An} .1 \mathrm{n}$ with none of the other sections in Kangra, indicating that Nurpur retains the uppermost part of the Siwalik Group.

The regional correlation suggests that the lower to middle Siwalik transition in Nurpur is present whereas the middle-upper Siwalik transition is present in all the sections except in Kangra section.

\section{Rate of sediment accumulation}

The rate of sediment accumulation in foreland basin provides useful information about lithospheric properties, the kinematic history of the thrust belt, and the rates of subsidence and flexural

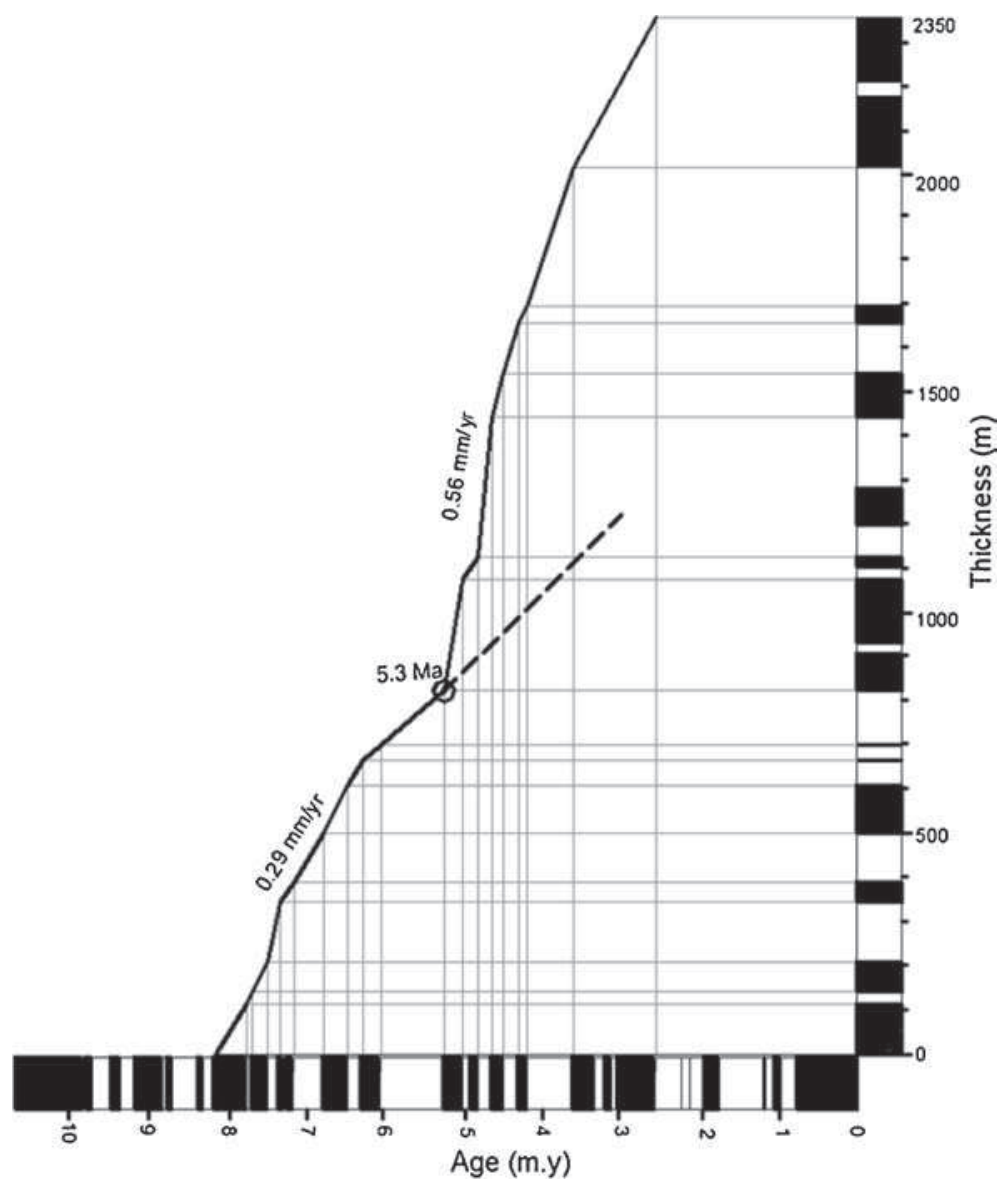

Figure 7. Plot of the sediment accumulation curve for Nurpur Siwaliks. Alternate black and white shaded region represents normal and reverse polarities, respectively in GPTS (Lourens et al. 2004). 
wave migration (Jordan et al. 1988). This approach has been exploited in Pakistan and north Indian part of the Himalayan foreland basin by Burbank et al. (1996). The rate of sediment accumulation is an accurate proxy for subsidence rate only when the elevation of the depositional surface is known through time and the rates of sediment compaction are calculable (Van Hinte 1978; Dickinson et al. 1988). Figure 7 is the representative of sediment accumulation rate of Nurpur section. The middle and upper Siwaliks are accumulated at the rate of $0.29 \mathrm{~mm} / \mathrm{yr}$ and $0.56 \mathrm{~mm} / \mathrm{yr}$, respectively.

\section{Conclusions}

The layered claystone and siltstone section in Nurpur gives consistent and very useful magnetostratigraphy results as far as upper Siwaliks of India are concerned. This section spans in age from 8.20 to $2.60 \mathrm{Ma}$. The magnetic remanence carrier in these sediments is found to be specular hematite. Sediment accumulation rates range from 0.29 to $0.56 \mathrm{~mm}$ year $^{-1}$ generally increasing through time in Siwalik Group. Future research on magnetostratigraphy of upper Siwalik sections will throw light on the correlation part in Indian Siwaliks.

\section{Acknowledgements}

Author thanks the Director, CSIR - NGRI for the permission to publish this work. He is indebted to A Ranga Rao, ONGC (Retd.) for his guidance and all time help. He is also thankful to Dr M S Bhalla, Scientist (Retd.), CSIR - NGRI for his support. He also thanks Dr A K Chaubey, Associate Editor and two anonymous reviewers for their valuable comments and suggestions which improved the paper.

\section{References}

Azzaroli A and Nappoleone G 1982 Magnetostratigraphic investigation of the upper Siwalik near Pinjor, India; Riv. Ital. Paleont. 87 739-762.

Barry J C, Lindsay E H and Jacobs L A 1982 Biostratigraphic zonation of the Middle and Upper Siwaliks of the Potwar Plateau of northern Pakistan; Palaeogeogr. Palaeoclimatol. Palaeoecol. Spec. Issue 37(1) 95-130.

Brozovik N and Burbank D 2000 Dynamic fluvial system sand gravel progradation in the Himalayan Foreland; Geol. Soc. Am. Bull. 112(3) 394-412.

Burbank D W, Beck R A and Mulder T 1996 The Himalayan Foreland; In: Asian Tectonics (eds) An Y and Harrison M (Cambridge, MA: Cambridge Univ. Press), pp. $149-188$.

Dickinson W R, Klute M A, Hayes M J, Janecke S U, Lundin E R, McKittrick M A and Olivares M D 1988 Palaeogeographic and paleotectonic setting of Laramide sedimentary basins in the central Rocky Mountain region; Bull. Geol. Soc. Am. 100 1023-1039.

Fisher R A 1953 Dispersion on a sphere; Proc. Roy. Soc. London A217 295-305.

François Chirouze, Guillaume Dupont-Nivet, Pascale Huyghe, Peter van der Beek, Tapan Chakraborti, Matthias Bernet and Véronique Erens 2012 Magnetostratigraphy of the Neogene Siwalik Group in the far eastern Himalaya: Kameng section, Arunachal Pradesh, India; J. Asian Earth Sci. 44 117-135.

Gautam P and Rosler W 1999 Depositional chronology and fabric of Siwalik group sediments in central Nepal from magnetostratigraphy and magnetic anisotropy; J. Asian Earth Sci. 17 659-682.

Johnson G D, Opdyke N D, Tandon S K and Nanda A C 1983 The magnetic polarity stratigraphy of the Siwalik Group at Haritalyangar (India) and a new last appearance datum for Amapithecus and Sivapithecus in Asia; Palaeogeogr. Palaeoclimatol. Palaeoecol. 44 223-249.

Johnson G D, Zeitiler P, Naeser C W, Johnson N M, Summers D M, Frost C D, Opdyke N D and Tahirkeli R A K 1982a The occurrence and fission ages of the late Neogene and Quaternary volcanic sediments, Siwalik Group, North Pakistan; Palaeogeogr. Palaeoclimatol. Palaeoecol. 37 63-93.

Johnson N M, Opdyke N D, Johnson G D, Lindsay E H and Tahirkeli R A K 1982b Magnetic polarity stratigraphy and ages of Siwalik Group of rocks of the Potwar Plateau, Pakistan; Palaeogeogr. Palaeoclimatol. Palaeoecol. Spec. Issue 37(1) 17-42.

Johnson N M, Stix J, Tauxe L, Cerveney P L and Tahirkeli R A K 1985 Palaeomagnetic chronology, fluvial processes and tectonic implications of the Siwalik Group near Chinji village, Pakistan; J. Geol. 93 27-40.

Jordan T E, Flemings P B and Beer J A 1988 Dating thrust fault activity by use of foreland basin strata; In: New perspectives in basin analysis (eds) Kleinspehn K L and Paola C (New York: Springer, Verlag), pp. 307-330.

Karunakaran C and Ranga Rao A 1976 Status of exploration of hydrocarbons in the Himalayan region: Contributions to stratigraphy and structure; Geol. Surv. India Misc. Publ. 41(V) 1-66.

Kodama K P 1997 A successful rock magnetic technique for correcting paleomagnetic inclination shallowing: Case study of the Nacimiento formation, New Mexico; J. Geophys. Res. 102 5193-5205.

Kotlia B S, Bhalla M S, Shah N and Rajgopalan G 1998 Palaeomagnetic results from the Paleocene-Holocene lake deposits of Bhimtal and Bhowali (Kumaun Himalaya) and Lamayaru (Ladakh Himalaya) with reference to the reversal events; J. Geol. Soc. India 51(1) 7-20.

Kotlia B S, Nakayama K, Phartiyal B, Tanaka S, Bhalla M S, Tokuoka T and Pande R N 1999 Lithology and magnetostratigraphy of the Upper Siwalik succession at Ramnagar (Uttar Pradesh), Kumaun Himalaya; Geol. Soc. India Memoir 44 411-423.

Kotlia B S, Nakayama K, Bhalla M S, Phartiyal B, Kosaka T, Joshi M, Sanwal J and Pandey R N 2001 Lithology and magnetic stratigraphy of the Lower-Middle Siwalik successions between Kathgodam and Ranibagh, Kumaun Himalaya; J. Geol. Soc. India 58 411-423.

Kotlia B S, Phartiyal B, Kosaka and Archna Bohra 2008 Magnetostratigraphy and lithology of MiocenePliocene Siwalik deposits between Tanakpur and Sukhidang, southeastern Uttarakhand Himalaya, India; Him. Geol. 29(2) 127-136.

Kirschvink J L 1980 The least-squares line and plane and the analysis of palaeomagnetic data; Geophys. J. Roy. Astron. Soc. 62 699-718. 
Kumaraval V, Sangode S J, Kumar Rohtash and Siva Siddaiah N 2005 Magnetic polarity stratigraphy of PlioPleistocene Pinjor Formation (type locality), Siwalik Group, NW Himalaya, India; Curr. Sci. 88(9) 1453-1461.

Lourens L J, Hilgen F J, Laskar J, Shackleton N J and Wilson D 2004 The Neogene period; In: A geologic time scale 2004 (eds) Gradstein F M, Ogg J G and Smith A G (Cambridge: Cambridge Univ. Press) (Chapter 20).

Nanda A C 2000 Siwalik Group: Palaeontologic and magnetostratigraphic aspects; Geol. Surv. India Misc. Publ. 64 $53-58$.

Nanda A C and Sehgal R K 1993 Siwalik mammalian faunas from Ramnagar ( $\mathrm{J}$ and $\mathrm{K}$ ) and Nurpur (HP) and lower limit of Hipparion; J. Geol. Soc. India 42 115-134.

Ojha T P, Butler R F, Quade J, DeCelles P G, Richards D and Upreti B N 2000 Magnetic polarity stratigraphy of the Neogene Siwalik Group at Khutia Khola, farwestern Nepal; Bull. Geol. Soc. Am. 112 424-434.

Opdyke N D, Lindsay E, Johnson G D, Johnson N M, Tahirkeli R A K and Mirza M A 1979 Magnetic polarity stratigraphy and vertebrate palaeontology of the upper Siwalik subgroup of northern Pakistan; Palaeogeogr. Palaeoclimatol. Palaeoecol. 27 1-34.

Pilgrim G E 1913 Correlation of the Siwaliks with mammal horizons of Europe; Rec. Geol. Surv. India 43(4) 264326.

Ranga Rao A, Agarwal R P, Sharma U N, Bhalla M S and Nanda A C 1988 Magnetic polarity stratigraphy and vertebrate palaeontology of the upper Siwalik subgroup of Jammu Hills, India; J. Geol. Soc. India 31(4) 361-385.

Ranga Rao A 1993 Magnetic polarity stratigraphy of upper Siwalik of northwestern Himalayan foothills; Curr. Sci. 64(11\&12) 863-873.

Ranga Rao A, Nanda A C, Sharma U N and Bhalla M S 1995 Magnetic polarity stratigraphy of the Pinjor Formation (upper Siwalik) near Pinjor, Haryana; Curr. Sci. 68(12) 1231-1236.

Ranga Rao A 1986 North-west Himalayan foothills: Its stratigraphical record and tectonic phases; Bull. ONGC 23(2) 107-128.

Rosler W and Appel E 1998 Fidelity and time resolution of the magnetostratigraphic record in Siwalik sediments: High-resolution study of a complete polarity transition and evidence for cryptochrons in Miocene fluviatile section; Geophys. J. Int. 135 861-875.

Sangode S J, Rohtas Kumar and Sumit K Ghosh 1996 Magnetic polarity stratigraphy of the Siwalik sequence of Haripur area (H.P.), NW Himalaya; J. Geol. Soc. India $47683-704$.

Sangode S J, Kumar R and Ghosh S K 1999 Palaeomagnetic and rock magnetic perspectives on the post-collisional continental sediments of Himalaya, India; Geol. Soc. India Memoir 44 221-248.

Sangode S J and Kumar R 2003 Magnetostratigraphic correlation of the late Cenozoic fluvial sequences from NW Himalaya, India; Curr. Sci. 84(8) 1014-1024.
Sanyal Prasanta, Bhattacharya S K, Kumar Rohtash, Ghosh S K and Sangode S J 2004 Mio-Pliocene monsoonal record from Himalayan foreland basin (Indian Siwalik) and its relation to vegetational change; Palaeogeogr. Palaeoclimatol. Palaeoecol. 205 23-41.

Sanyal Prasanta, Bhattacharya S K, Rohtash Kumar, Ghosh S K and Sangode S J 2005 Palaeoenviromental reconstruction in Late Miocene: A case study based on early diagenetic carbonate cement from the Indian Siwalik; Palaeogeogr. Palaeoclimatol. Palaeoecol. 228(2-3) 245259.

Sehgal R K and Nanda A C 2002 Age of the fossiliferous Siwalik sediments exposed in the vicinity of Nurpur, District Kangra, Himachal Pradesh; Curr. Sci. 82(4) 392-395.

Sinha Subhajit, Sangode S J, Kumar R and Ghosh S K 2005 Accumulation history and tectonic significance of the Neogene continental deposits in the central sector of the Himalayan Foreland basin; Him. Geol. 26(2) 387-408.

Sudheer Kumar 2004 Magnetic polarity stratigraphy of the Siwalik sediments from Ramnagar basin, NW Himalaya; J. Geol. Soc. India 64 199-210.

Tandon S K, Kumar R, Koyama M and Nitsuma N 1984 Magnetic polarity stratigraphy of the upper Siwalik subgroup east of Chandigarh, Punjab sub-Himalaya, India; J. Geol. Soc. India 25(1) 45-55.

Tauxe L and Kent V D 1984 Properties of a detrital remanence carried by haematite from study of modern river deposits and laboratory redeposition experiments; Geophys. J. Roy. Astron. Soc. 76 543-561.

Tauxe L and Badgely C 1988 Stratigraphy and remanence acquisition of a paleomagnetic reversal in alluvial Siwalik rocks of Pakistan; Sedimentology 35 697-715.

Tauxe L, Constable C G, Stokking L and Badgely C 1990 Use of anisotropy to determine the origin of characteristic remanence in the Siwalik red beds of northern Pakistan; J. Geophys. Res. 95 4391-4404.

Van Hinte J E 1978 Geohistory analysis - application of micropaleontology in exploration geology; AAPG Bull. 62 201-222.

Venkateshwarlu M 1996 Magnetostratigraphic studies of the Siwalik sediments at Nurpur and Kotla, Kangra district, Himachal Pradesh, India; Ph.D thesis, Osmania University.

Venkateshwarlu M, Poornachandra Rao G V S, Srinivasa Rao B and Bhalla M S 2005 Upper Miocene Magnetic Polarity Stratigraphy of Kotla Section in the NW Himalayan Foreland Basin; XXII Convention of Indian Association of Sedimentologists (IAS), Wadia Institute of Himalayan Geology, Dehra Dun.

Venkateshwarlu M 2008 Magnetic polarity stratigraphy of Kotla section, Himachal Pradesh, NW Himalayas; $J$. Geol. Soc. India 72 533-542.

Venkateshwarlu M 2011 Magnetostratigraphy of foot-hill sedimentary sequences of the Himalaya; Lambert Academic Publishing, Germany, 114p. 